\title{
Populasi dan Manajemen Pemeliharaan serta Pola Pemasaran Ternak Itik (Studi Kasus di Desa Pematang Balam Kecamatan Hulu Palik Kabupaten Bengkulu Utara)
}

\author{
Population and Maintenance Management as well as Marketing Patterns of Ducks (Case \\ Study in Pematang Balam Village, Hulu Palik District, North Bengkulu Regency)
}

\author{
B. Brata, E. Soetrisno, T. Sucahyo dan B. D. Setiawan \\ Jurusan Peternakan, Fakultas Pertanian, Universitas Bengkulu \\ Jln. WR.Supratman, Kandang Limun, Bengkulu \\ Corresponding email: Biengbrata@gmail.com
}

\begin{abstract}
This research was aimed to identify the development of the population of ducks and find out the management system and marketing patterns of ducks. This research was conducted for four months in Pematang Balam Village, Hulu Palik Subdistrict, North Bengkulu Regency, Bengkulu Province. The method used was the survey method, with interviews directly to farmers. The variables observed were respondent's identity, duck population, maintenance management, and livestock marketing patterns. The results of the study were presented in tabular form, and analyzed descriptively. Based on the results of the study of the population of ducks from 10 respondents were 187 ducks, the management system for raising ducks in Pematang Balam village was still inefficient, and furthermore, the marketing patterns for duck in Pematang Balam Village were carried out by selling through collectors, and determining direct prices by breeders. It was expected that with the identification of population identification and maintenance management and marketing patterns that existed at this time, the development of duck farming could develop well and could have a positive impact on improving the management system.
\end{abstract}

Key words: population, maintenance management, marketing patterns, ducks, Bengkulu

\begin{abstract}
ABSTRAK
Penelitian ini bertujuan untuk dapat mengidentifikasi perkembangan populasi ternak itik dan mengetahui sistem manajemen serta pola pemasaran ternak itik. Penelitian ini dilakukan pada bulan Maret s/d Juni 2018 di Desa Pematang Balam Kecamatan Hulu Palik Kabupaten Bengkulu Utara Provinsi Bengkulu. Metoda yang dilakukan adalah metoda survey, dengan wawancara langsung kepada peternak. Peubah yang diamati adalah identitas responden, populasi itik, manajemen pemeliharaan, dan pola pemasaran ternak. Hasil penelitian disajikan dalam bentuk tabel, dan dianalisis secara deskriptif. Berdasarkan hasil penelitian populasi ternak itik dari 10 responden yang ada sebanyak 187 ekor itik, sistem manajemen pemeliharan ternak itik di Desa Pematang Balam masih belum efesien, dan selanjutnya untuk pola pemasaran ternak itik di Desa Pematang Balam dilakukan dengan cara dijual melalui pedagang pengumpul, dan penentuan harga langsung oleh peternak. Diharapkan dengan adanya infromasi identifikasi populasi dan manajamen pemeliharaan serta pola pemasaran yang ada pada saat ini, maka dalam pengembangannya usaha peternakan itik ini dapat berkembang dengan baik dan bisa memberikan dampak positif pada peningkatan sistem manajemennya.
\end{abstract}

Kata Kunci: populasi, manajemen pemeliharaan, pola pemasaran, itik, Bengkulu

\section{PENDAHULUAN}

Peternakan merupakan salah satu subsektor pertanian yang sangat diperlukan untuk dapat memenuhi kebutuhan pangan masyarakat, terutama kebutuhan gizi protein hewani. Komoditas terbesar di peternakan saat ini berasal pada sektor perunggasan, hampir $70 \%$ di Sektor peternakan dan didominasi perunggasan (Yulistiya, 2016). Usaha Ternak Itik merupakan salah satu usaha peternakan yang banyak memberikan manfaat dalam memenuhi kebutuhan pangan yang terus meningkat dan pencitaan lapangan kerja. Tingkat pendapatan masyarakat di bidang pertanian atau peternakan belum sepenuhnya dapat mencukupi kebutuhan hidupnya, karena hasil kegiatan yang ada saat ini tidak dapat diandalkan sebagai pendapatan utama (Aziz, 2019). Kondisi geografis, ekologi ketersediaan air dan kesuburan lahan di beberapa wilayah di 
Bengkulu memiliki karaterisik yang cocok untuk usaha ternak itik. Ternak itik juga dapat memberikan produk ganda sebagai penghasil daging dan juga dapat sebagai penghasil telur. Daging dan telur sebagai produk ternak itik mengandung gizi yang lengkap dan seimbang seperti protein, lemak, karbohidrat, vitamin dan mineral. Dampak dari mengkonsumsi protein hewani berasal dari daging dan telur yang rendah yakni berpengaruh pada kualitas Sumber Daya Manusia menjadi rendah, kondisi tersebut disebabkan pada kondisi persaingan global yang semakin ketat (Margaretha and Ramadhan, 2010).

Produktivitas ternak, temasuk ternak itik ditentukan oleh dua faktor utama yaitu, faktor genetik dan lingkungan. Oleh karena itu perbaikan mutu genetik itik dan lingkungan manajemen pemeliharaan akan meningkatkan produktivitas ternak tersebut. Kebanyakan peternak memelihara ternak itik masih dengan cara tradisional yakni dengan cara dilepas di area lahan persawahan (Mangisah, 2016). Dengan sempitnya areal pengembalaan dan banyaknya kasus kematian ternak akibat keracunan pestisida, maka cara ini makin kurang efektif. Salah satu usaha yang dipandang mampu mengatai masalah ini adalah dengan mengalihkan pada sistem pemeliharan yang intensif (Suharno dan Setiawan, 2012).

Manajemen pemasaran merupakan proses kegiatan aktivitas menyalurkan produk dari produsen ke konsumen. Pemasaran merupakan ujung tombak kegiatan ekonomi dalam sektor agribisnis peternakan. Peternak atau pengusaha yang menghasilkan produk peternakan pasti menginginkan produknya sampai dan diterima oleh konsumen yang harus melalui beberapa kegiatan pemasaran (Rahardi dan Hartono, 2003).

Desa Pematang Balam, Kecamatan Hulu Palik, Kabaupaten Benkulu Utara merupakan salah satu Desa yang ada di Provinsi Bengkulu yang berbatasan sebelah Utara dengan Desa Air Tik Gambir, sebelah Selatan dengan Air Lado, sebelah Barat dengan Air Telatang dan sebelah Timur dengan Bukit Barisan. Berdasarkan data desa dan kelurahan tahun pada tahun 2017, jumlah penduduk desa Pematang Balam sebanyak 1.609 orang dengan jumlah kepala keluarga sebanyak 426 kepala keluarga. Mata pencarian masyarakat mayoritas adalah petani dengan jumlah 900 orang dan diikuti oleh buruh sebanyak 130 orang dan peternak sebanyak 219 orang dan sisanya pegawai negeri dan lain-lain. Berdasarkan luas area yang ada di Desa Pematang Balam terdapat 1752 ha yang terdiri dari pemukinan 300 ha, perkebunan, 427 ha, pekarangan, 159 ha, persawahan 869 ha dan sisanya prasara umum dan lain-lain.

Ternak yang dipelihara oleh masyarakat desa Pematang Balam adalah sapi 800 ekor, ayam kampung 1500 ekor, ayam broiler ekor, itik 100 ekor, angsa 4 ekor dan kambing sebanyak 300 ekor. Dilihat dari kepemilikan ternak itik, jumlah pemilk ternak sapi 400 orang, ayam kampung 500 orang, ayam broiler sebanyak 3 orang, kambing sebanyak 150 orang dan itik sebanyak 25 orang. Berdasarkan data yang ada dan dengan dengan ketersedian lahan yang cukup, jumlah peternak itik yang cukup banyak namun mempunyai populasi yang sedikit maka pengembangan ternak itik salah satu usaha yang cocok dikembangkan di desa Pematang Balam.

Berdasarkan uraian di atas, terdapat beberapa masalah yang terjadi pada pengembangan ternak itik di Desa Pematang Balam yaitu 1) perlu pengkajian populasi ternak itik yang sesuai dengan potensi daerah dan kepemilikannya, 2) mengkaji manajemen pemeliharaan itik sesuai dengan tingkat produktivitasnya, 3) mengkaji pola pemasaran ternak itik sehingga tidak menghadapi nilai jual yang rendah. Luaran yang diperoleh dari hasil penelitian ini, dapat memperbaiki data tentang populasi ternak itik serta melakukan introduksi system manajemen pemeliharaan serta pemasaran ternak itik khususnya di desa Pematang Balam kecamatan Hulu Palik kabupaten Bengkulu Utara. 


\section{MATERI DAN METODE}

Penelitian ini dilaksanakan pada bulan Maret 2018 s/d Juni 2018 di Desa Pematang Balam, Kecamatan Hulu Palik, Kabupaten Bengkulu Utara. Alat dan bahan yang digunakan dalam penelitian ini antara lain seperti kuisioner, alat tulis dan kamera. Disamping itu sejumlah peternak itik yang tergabung dalam kelompok maupun individu Desa Pematang Balam, Kecamatan Hulu Palik, Kabupaten Bengkulu Utara.

\section{Tahapan Penelitian}

\section{Survey Pendahuluan}

Penelitian survey merupakan suatu teknik pengumpulan dari informasi yang dilakukan dengan cara menyusun daftar pertanyaan yang diajukan pada responden. Data yang diambil dalam penelitian ini yaitu data primer dan data sekunder (Kalangi, 2017). Survei pendahuluan dilakukan dengan tujuan untuk menentukan lokasi penelitian dan keberadaan peternak Itik di Desa Pematang Balam, Kecamatan Hulu Palik, Kabupaten Bengkulu Utara. Hasil survei yang telah dilakukan dianalsis apakah program penenelitian yang akan dilakukan sudah tepat atau perlu pembenahan lokasi penelitian.

\section{Penentuan Responden}

Responden di tentukan secara sengaja (purposive) yaitu seluruh peternak itik yang ada di Desa Pematang Balam, Kecamatan Hulu Palik, Kabupaten Bengkulu Utara. Berdasarkan penelitian data peternak itik yang ada di Desa Pematang Balam, Kecamatan Hulu Palik, Kabupaten Bengkulu Utara.

\section{Metode Pengumpulan Data}

Data yang dikumpulkan dalam penelitian ini adalah primer dan sekunder. Data primer diperoleh melalui pengamatan langsung ke lokasi penelitian dan mendatangi langsung peternak yang dipilih sebagai sampel dengan cara wawancara (dept interview) dan menunjukkan daftar pertanyaan atau kuisioner yang telah dipersiapkan untuk mendapatkan informasi dari peternak. Data primer terdiri dari: Identitas responden, manajemen pemeliharaan ternak itik (manajemen bibit, reproduksi, kandang dan fasilitasnya, pemberian pakan dan pemberantasan penyakit), populasi ternak, pola pemasaran ternak itik, dan data sekunder dapat diperoleh dari data dan catatan yang sudah ada sebelumnya. Data tersebut didapat dari intansi dan lembaga-lembaga yang berkaitan dengan penelitian ini maupun literatureliteratur ataupun pustaka yang sudah ada.

\section{Data yang Dikumpulkan}

\section{Identitas Responden}

Identitas Peternak meliputi nama peternak, alamat peternak, umur peternak, pekerjaan peternak, pendidikan terakhir peternak, tujuan pemeliharaan, dan lama beternak itik.

\section{Populasi Ternak Itik}

Data yang berkaitan dengan populasi yang dikumpulkan meliputi: jumlah ternak (induk, jantan, anak) dan jumlah kematian. Populasi ternak itik diketahui dengan cara mensesus ternak itik dan wawancara langsung ke peternak yang ada dilokasi penelitian.

\section{Manajemen Pemeliharaan}

Manajemen pemeliharaan diketahui dengan cara mengamati secara langsung sistem pemeliharaan pada setiap peternak itik yang ada di Desa Pematang Balam, Kecamatan Hulu Palik, Kabupaten Bengkulu Utara. Data yang berkaitan dengan manajemen yang dikumpulkan meliputi 1). pemilihan bibit (bibit ternak itik, asal bibit, jenis bibit, umur bibit, dan bobot bibit), 2) reproduksi (cara perkawinan, rasio pejantan dan betina, perlakuan pejantan dan betina saat kawin, kandang khusus untuk kawin), 3) kandang dan fasilitasnya (konstruksi bahan kandang, ukuran kandang, perlengkapan kandang, bentuk kandang, arah kandang), 4) pemberian pakan (waktu dan frekuensi pemberian pakan, 
jumlah pemberian pakan, ketersediaan pakan kandang, jenis pakan yang diberikan, 5) pemberantasan penyakit (selalu menjaga kebersihan lingkungan kandang, pencegahan penyakit itiki, obat yang digunakan, waktu pencegahan penyakit, dan 6) pasca panen (cara penjualan produksi ternak itik, harga pemaaran ternak itik).

\section{Pola Pemasaran Ternak Itik}

Variabel yang dapat diamati dalam pola pemasaran yaitu: cara penjualan ternak, kriteria penentuan harga, dan waktu penjualan ternak.

\section{Analisis Data}

Data yang diperoleh ditabulasi dan disajikan dalam bentuk table atau grafik lalu di bahas secara deskriptif.

\section{HASIL DAN PEMBAHASAN}

\section{Identitas Responden}

Usaha ternak itik petelur pada umumnya merupakan usaha skala kecil (peternakan rakyat) sehingga hanya menggunakan tenaga kerja keluarga. Usaha ternak itik petelur diminati oleh masyarakat karena pemeliharaannya yang mudah dilakukan. Berdasarkan Tabel 1, dapat dilihat jumlah responden sebanyak 10 orang dari satu Desa yaitu Desa Pematang Balam Kecamatan Hulu Palik Kabupaten Bengkulu Utara. Umur responden bervariasi, umur responden tertua 62 tahun dan temuda 27 tahun. Umur responden 20-40 tahun sebanyak 30\%, 41-55 sebanyak 30\% dan 5670 sebanyak $40 \%$. Usia produktif merupakan modal utama dalam pengembangan suatu usaha peternakan karena di usia ini peternak memeliki peluang yang lebih besar untuk mengembangkan usahanya. Kemampuan dan kondisi fisik pada manusia akan optimal jika berada pada skala umur yang masih produktif, dimana usia yang masih produktif adalah umur 25-64 tahun (Setiawan, 2019). Hal ini sesuai dengan yang dikemukakan oleh Pasaribu (2007) bahwa usia akan sangat mempengaruhi produktivitas kerja, dimana akan mengalami penurunan dengan semakin bertambahnya usia seseorang.

Tabel 1. Identitas Responden Penelitian

\begin{tabular}{llcc}
\hline No & Karekteristik & Jumlah Responden & Presentase (\%) \\
\hline 1 & Jumlah responden & 10 & 100 \\
2 & Alamat peternak & & 100 \\
& Pematang Balam & 10 & 30 \\
& Umur Responden & & 30 \\
& $20-40$ & 3 & 40 \\
& $41-55$ & 3 & 20 \\
4 & $56-70$ & 4 & 20 \\
4 & Pendidikan & 2 & 40 \\
& Tamat SD & 2 & 20 \\
& Tamat SMP & 4 & 90 \\
& Tamat SMA & 2 & 10 \\
& Tamat Sarjana (S1) & & 50 \\
& Pekerjaan Pokok & 9 & 30 \\
& Petani & 1 & 20 \\
& PNS & & 100 \\
& Lama pemeliharaan ternak itik & 5 &
\end{tabular}

Sumber: Hasil Penelitian (2018)

Karakteristik peternak itik di Desa Pematang Balam Kecamatan Hulu Palik
Kabupaten Bengkulu berdasarkan tingkat pendidikan beragam yaitu SD sebanyak $20 \%$, 
SMP sebanyak 20\%, SMA sebanyak $40 \%$ dan Sarjana sebanyak 20\%. Menurut Setiawan (2019), tingkat pendidikan formal ikut mempengaruhi peternak dalam mengelola jenis usahanya, semakin tinggi pendidikan maka wawasannya akan semakin meningkat dan semakin mudah dalam menerima inovasi serta teknologi yang berkembang. Mata pencarian atau pekerjaan pokok responden peternak itik di Desa Pematang Balam Kecamatan Hulu Palik Kabupaten Bengkulu Utara sebagian besar petani sawit sebanyak $90 \%$ dan PNS sebanyak $10 \%$. Kebanyakan petenak yang ada di Desa Pematang Balam Kecamatan Hulu Palik Kabupaten Bengkulu Utara memilih beternak sebagai pakerjaan sampingan atau tambahan, di luar pekerjaan pokoknya sebagai petani. Mata pencarian atau pekerjaan pokok responden peternak itik di Desa Pematang Balam Kecamatan Hulu Palik Kabupaten Bengkulu Utara sebagian besar petani sawit sebanyak 90\% dan PNS sebanyak $10 \%$. Kebanyakan petenak yang ada di Desa Pematang Balam Kecamatan Hulu Palik Kabupaten Bengkulu Utara memilih beternak sebagai pekerjaan sampingan atau tambahan, di luar pekerjaan pokoknya sebagai petani.

Lama pemeliharaan tenak itik juga bervariasi. Pemeliharaan terlama adalah 8 tahun dan terendah 8 bulan. Lama pemeliharan 1-18 bulan sebanyak 50\%, lama pemeliharan 17-36 bulan sebanyak 30\% dan lama pemeliharan diatas 37 bulan sebanyak 20\%. Lama pemeliharaan sangat mempengaruhi populasi ternak itik, semakin lama beternak maka pengalaman yang didapat juga semakin tinggi dalam pemeliharaan. Untuk tujuan pemeliharaan ternak itik dari ke-10 responden bertujuan untuk menambah pendapatan keluarga. Menurut Hardjosworo et al. (2002) bahwa itik merupakan ternak pertama yang dibudidayakan dan dipasarkan sebagai sumber pendapatan, disamping itu, itik mempunyai daya tahan yang lebih baik dibandingkan unggas lainnya.

\section{Populasi Ternak Itik}

Ternak itik merupakan salah satu komoditi unggas yang mempunyai peran cukup penting sebagai penghasil telur dan daging untuk mendukung ketersediaan protein hewan (Anwar, 2015). Populasi dan hasil produksi ternak itik yang berada di Desa Pematang Balam, Kabupaten Bengkulu Utara dapat dilihat pada Tabel 2. Pada Tabel ini menunjukkan bahwa populasi ternak itik yang banyak tidak menjamin produksi telur akan ikut tinggi. Hal ini tercermin dari data diatas yang menyatakan bahwa populasi 16 28 dapat menghasilkan produksi telur dengan presentase $\quad 68,75-\quad 76,46 \%$ sedangkan populasi ternak itik yang terdiri dari 235 hanya sebatas $68,08 \%$.

Tabel 2. Populasi dan produktivitas peternakan rakyat

\begin{tabular}{ccccc}
\hline \multirow{2}{*}{ Responden } & Populasi & & Produksivitas & Persentase (\%) \\
& Starter- grower & Layer & & \\
\hline 1 & - & 11 & 5 & 45,45 \\
2 & - & 12 & 6 & 50,00 \\
3 & - & 13 & 7 & 53,84 \\
4 & - & 13 & 9 & 69,23 \\
5 & - & 16 & 11 & 68,75 \\
6 & - & 17 & 13 & 76,46 \\
7 & - & 22 & 15 & 68,18 \\
8 & - & 23 & 17 & 73,91 \\
9 & - & 28 & 20 & 71,42 \\
10 & 20 & 235 & 160 & 68,08 \\
\hline
\end{tabular}

Sumber: Hasil Penelitian (2018) 
Produksi telur tidak hanya dipengaruhi oleh populasi saja tetapi ada factor lain seperti faktor pakan. Hal tersebut sejalan dengan pendapat Subagja (2017) bahwa jumlah pemberian pakan itik juga berpengaruh terhadap produksi telur itik. Pasalnya itik tidak mampu menghasilkan telur jika jumlah pakan yang dikonsumsi tidak memenuhi kebutuhan produksinya. Selain dari pakan juga ada manajemen pemeliharaan yang dilakukan peternak kepada ternaknya sendiri. Hal ini sesuai dengan pendapat Rasyaf (1991), peternak yang memelihara ternaknya dengan baik akan mendapatkan laju produksi yang lebih baik dari pada peternak yang memelihara ternak dengan semaunya. Perhatian kepada ternak, kebersihan kendang dan kebersihan dalam pemeliharaan sangat diperlukan untuk mendapat jumlah produksi yang tinggi.

\section{Manajemen Pemeliharaan}

\section{Pemilihan Bibit Ternak Itik}

Berkaitan dengan proses

pemeliharaan, maka faktor yang beperan dalam proses tesebut adalah faktor pemilihan bibit. Untuk pemilihan bibit ternak itik yang diamati ialah bibit asal bibit, jenis bibit dan lokasi pemeliharaan dapat dilihat pada Tabel 3 berikut ini:

Tabel 3. Pemilihan bibit ternak itik

\begin{tabular}{llcc}
\hline No & Keterangan & Jumlah responden & Persentase (\%) \\
\hline 1 & Asal bibit & 6 & 60 \\
& Beli bibit itik (DOD) & 4 & 40 \\
& Budidaya & & 0 \\
2 & Jenis bibit & 0 & 100 \\
& Pedaging & 10 & 30 \\
& Petelur & & 70 \\
& Lokasi pemeliharaan & 3 & 0 \\
& Intensif & 7 & \\
& Semi-Intensif & 7 &
\end{tabular}

Sumber: Hasil penelitian (2018)

Dapat dilihat pada Tabel 3 bahwa peternak lokal di Desa Pematang Balam Kecamatan Hulu Palik Kabupaten Bengkulu Utara mengadakan bibit dengan cara membeli DOD sebanyak $60 \%$ dan cara budidayadiri sebanyak $40 \%$. Hal ini dikarenakan kurangnya pemahaman dalam membudidayakan ternak itik karena sering terjadi kegagalan saat menetas. Dalam sistem menejemen pemeliharaan itik, asal bibit merupakan hal yang mendasar dari jumlah produksi yang didapatkan. Dengan memilih bibit yang baik memiliki keseragaman dan keunggulan dalam jumlah produksi. Masalah yang dihadapi peternak selama ini iyalah belum adanya pembibitan yang memadai untuk menghasilkan pembibitan yang berkualitas (Prasetyo et al., 2010).

Pemilihan bibit didasarkan pada jenis ternak, turunan, dan postur. Bibit harus jelas jenisnya, berasal dari peternakan yang memiliki catatan kinerja tentunya dengan kriteria-kriteria dari bibit tersebut. Bibit yang akan diternakkkan di seleksi terlebih dahulu, dengan menyeleksi bibit yang sehat atau tidak terkena penyakit, dan mampu berkembang biak sebaik tetuanya (Raharjo, 2009).

Dalam pengadaan DOD maupun fase indukan (layer) memiliki keuntungan dan kerugian masing-masing. Salah satu keuntungan memilih memelihara pada fase anakan (starter) hingga fase pertumbuhan (grower) harga relatif lebih murah, namun pemeliharaannya membutuhkan waktu yang panjang atau lama berkisar 6-8 bulan untuk berproduksi menghasilkan telur. Dengan demikian dalam kurung waktu yang lama, itik dapat terserang penyakit atau predator lain sebelum berproduksi, sehingga ternak 
itik banyak mati sebelum berproduksi. Bibit indukan memiliki waktu yang singkat untuk berproduksi, namun kekurangannya adalah harga bibit ternak itik yang berasal dari indukan harganya relatif lebih mahal dibandingkan dengan fase starter.

Sistem pemeliharaan dengan pola intensif, yaitu itik dipelihara di dalam kandang dan seluruh aktivitas dilakukan di dalam kandang seperti pemberian pakan, kesehatan dan kontrol pertumbuhannya (Rahayu, 2019). Sistem pemeliharaan ternak itik didesa pematang balam $30 \%$ menggunakan sistem secara intensif. Sistem pemeliharan secara semi-intensif itik di umbar (digembalakan) serta dikandangkan dengan sistem ini pakan yang diperoleh selain dari diumbar juga diberikan pakan pada saat pengandangan, sitem pemeliharan ternak secara semi-intensif sebanyak $70 \%$. Perubahan sistem pemeliharaan ternak itik ke arah intensif memerlukan upaya peningkatan kualitas bibit yang hanya bisa dicapai melalui pengembangan sistem pembibitan ternak itik (Prasetyo, 2006).

\section{Reproduksi.}

Reproduksi ternak itik dilakukan secara tradisional dengan perbandingan jantan dan betina 1:7 ekor. Pada dasarnya reprouksi ternak itik tanpa adanya introduksi ternak itik unggul. Itik umumnya mengalami pubertas (masak kelamin) pada kisaran umur 20-22 minggu dengan masa produksi sekitar 15 bulan. Jika dibandingkan dengan ayam ras, itik menempati posisi kedua terbesar sebagai penghasil telur (30-40\%) sebagai total konsumsi telur Indonesia (Sa'diyah, 2016).

\section{Kandang dan Fasilitasnya}

Kandang dan fasilitasnya merupakan salah satu hal yang perlu di perhatikan untuk menentukan hasil produksi yang diperoleh. Adapun persyaratan kandang yang harus dipenuhi adalah mudah dibersihkan, sirkulasi udara lancar dan cukup mendapatkan sinar matahari (Sibuea, 2016). Fungsi dari kandang sebagai tempat berlindung, beristirahat dan juga tempat bertelur, serta fasilitas kandang berfungsi untuk mempemudah peternak saat pengawasan. Berkaitan dengan sistem kandang dan fasilitasnya meliputi kontruksi kandang, perlengkapan kandang, bentuk kandang dapat dilihat pada Tabel 4 .

\section{Konstruksi Bahan Kandang}

Kontruksi kandang perlu diperhatikan, karena kontruksi kandang yang baik dapat memberikan rasa nyaman dan aman pada ternak itik (Herman, 2002). Kontruksi kandang yang diterapkan meliputi atap kandang, dinding kandang, lantai kandang, perlengkapan kandang dan bentuk kandang dapat dilihat pada Tabel 4.

\section{Atap Kandang}

Bahan yang tersedia untuk dijadikan atap kandang banyak tersedia, yaitu seng, genteng, rumbia, dan alang-alang. Sebelum memutuskan pemilihan bahan yang akan dibuat atap kandang, sebaiknya harus memperhatikan ketahanan bahan, efisiensi penggunaan dan harga bahan yang akan digunakan sebagai atap kandang tersebut (Herman, 2002). Pada Tabel 4 terlihat bahwa atap kandang yang digunakan oleh peternak atau responden $100 \%$ dari seng. Bila dilihat dari efisiensinya atap seng kurang bagus bila digunakan sebagai atap karena selain mahal, atap seng juga tidak menyerap panas. Dengan demikian akan menyebabkan suhu pada ruangan akan tinggi, akan berdampak pada fisiologi ternak itik seperti stress akibat pans, sehingga dapat menurunkan produktivitas ternak itik. Dalam penggunaan atap kandang sebaiknya dipilih bahan yang meyerap panas, misalnya genteng atau rumbia, karena kedua bahan atap tersebut sama-sama dapat menyerap panas dalam penggunaanya dan harga relatif lebih murah.

\section{Dinding Kandang Itik}

Dinding kandang sangat diperlukan untuk melindungi ternak itik dari berbagai gangguan dari luar seperti angin, predator, terik matahari, dan air hujan. Pada tabel 3 terlihat 6 peternak atau responden menggunak papan sebagai bahan dinding kandang, dan 4 peternak atau responden yang 
menggunakan bambu sebagai bahan dinding diternakkan.

kandang pada kandang ternak itik yang

Tabel 4. Sistem perkandangan ternak itik

\begin{tabular}{|c|c|c|c|}
\hline No & Karakteristik & Jumlah Responden & Presentase \\
\hline \multirow[t]{12}{*}{1} & $\begin{array}{l}\text { Kontruksi Bahan kandang } \\
\text { a.) Atap kendang }\end{array}$ & & \\
\hline & Seng & 10 & 100 \\
\hline & Rumbia & 0 & 0 \\
\hline & Genteng & 0 & 0 \\
\hline & b.) dinding kendang & & \\
\hline & papan & 6 & 60 \\
\hline & Seng & 0 & 0 \\
\hline & Bambu & 4 & 40 \\
\hline & c.) Lantai kendang & & \\
\hline & Bambu & 0 & 0 \\
\hline & Semen & 0 & 0 \\
\hline & Tanah & 10 & 100 \\
\hline \multirow[t]{6}{*}{2} & Perlengkapan Kandang & & \\
\hline & kandang produksi & 10 & 100 \\
\hline & tempat pakan & 10 & 100 \\
\hline & tempat minum & 10 & 100 \\
\hline & kandang tetas & 1 & 10 \\
\hline & kandang DOD & 1 & 10 \\
\hline \multirow[t]{2}{*}{3} & Bentuk kandang & & \\
\hline & kandang koloni & 10 & 100 \\
\hline
\end{tabular}

Sumber: Hasil penelitian (2018).

\section{Lantai Kandang Itik}

Pembuatan lantai kandang dapat menggunakan bahan-bahan seperti bahan dari kawat, bambu, papan, dan tanah (Basuki, 1985). Bahan lantai kandang yang digunakan oleh peternak atau responden di Desa Pematang Balam, Kecamatan Hulu Palik, Kabupaten Bengkulu Utara dapat dilihat pada tabel dapat terlihat 10 responden menggunakan tanah sebagai lantai kandang pada kandang ternak itik yang diternakkan. Pengguanaan tanah sebagai lantai kandang disebabkan karena responden yang beternak itik masih dalam skala kecil sehingga modal yang dikeluarkan masih relatif sedikit.

\section{Perlengkapan Kandang}

Berdasarkan tabel dan grafik, dapat dilihat ke-10 peternak atau responden memiliki kandang produksi, tempat makan, dan tempat minum. Peternak atau responden yang memiliki kandang tetas sebanyak 1 peternak atau responden, dan kandang DOD sebanyak 1 peternak dan responden. Hal ini disebabkan karena ke-9 peternak atau responden lainnya beternak itik lebih sedikit.

\section{Bentuk Kandang}

Bentuk kandang yang digunakan oleh peternak atau responden di Desa Pematang Balam, Kecamatan Hulu Palik, Kabupaten Bengkulu Uatra adalah bentuk kandang koloni. Penggunaan kandang koloni memiliki keuntungan tersendiri, keuntungan penggunaan kandang koloni terletak pada biaya yang relatif murah, dan kelemahan menggunakan kandang koloni adalah pada saat pemberian pakan tidak efektif disebabkan karena pada ternak itik berebut pakan pada saat pakan diberika. 


\section{Manajemen Pemberian Pakan Itik}

Tabel 5. Manajemen pemberian pakan ternak itik

\begin{tabular}{llcc}
\hline No & Keterangan & Jumlah Responden & Presentase (\%) \\
\hline 1 & Sumber Pakan & 10 & 100 \\
& Beli & 0 & 0 \\
& Milik Sendiri & 0 & 0 \\
& Ternak mencari Pakan Sendiri & & \\
& Jumlah Pakan Yang Diberikan & 9 & 90 \\
& $1-10(\mathrm{Kg})$ & 0 & 0 \\
& $11-20(\mathrm{Kg})$ & 1 & 10 \\
& $21-30(\mathrm{Kg})$ & & 0 \\
3 & Bahan Makanan & 10 & 100 \\
& Dedak dan Konsentrat & 0 & 0 \\
& Waktu Pemberian Pakan & 10 & 100 \\
& Siang & & 0 \\
& Sore & 0 &
\end{tabular}

Sumber: Hasil Penelitian (2018)

Sumber pakan yang diberikan oleh petenak di sebayak 100\% sumber pakan yang diberikan berasal dari beli. Jumlah pakan yang diberikan dalam seharinya $1-10 \mathrm{~kg}$ sebanyak $90 \%$, dan $21-30 \mathrm{~kg}$ sebanyak $10 \%$. Hal ini sesuai dengan yang dikemukakan oleh Gumelar (2016) bahwa, pemberian pakan yang diberikan disesuaikan dengan jumlah itik per kandang, suhu lingkungan, kondisi kesehatan, dan bobot badan. Bahan pakan yang diberikan oleh seluruh responden/peternak berupa dedak dan konsentrat. Waktu pemberian pakan sendiri diberikan 2 kali sehari yaitu pada pagi dan sore hari, dan frekuensi pemberian pakan diberikan 2 kali sehari. Ketersediaan pakan pada ternak itik diberi secara non ad libitum, sehingga pakan yang diberikan tidak tercecer. Pakan yang palatabel (disukai) akan dikonsumsi ternak Itik dalam jumlah yang lebih banyak daripada ransum yang tidak palatabel, ketika kebutuhan gizi terpenuhi dengan baik, maka pertambahan bobot badan pun akan lebih baik dan menghasilkan efisiensi penggunaan ransum yang baik pula (Toana, 2008).

\section{Manajemen Pemberantasan Penyakit}

Manajemen pemberantasan penyakit meliputi: menjaga kebersihan kandang, pencegahan penyakit, dan waktu pencegahan penyakit dapat dilihat pada Tabel 6 .

Tabel 6. Pencegahan dan pengobatan penyakit oleh peternak

\begin{tabular}{llcc}
\hline No & Karakteristik & Jumlah Responden & Presentasi \\
\hline 1 & Menjaga kebersihan kandang & 10 & 100 \\
& Ya & 0 & 0 \\
& Tidak & & 0 \\
& Pencegahan penyakit & 0 & 100 \\
& Vaksinasi & 10 & 100 \\
& Sanitasasi & & 0 \\
& waktu pencegahan penyakit & 10 & 0 \\
& Sebelum terserang & 0 & \\
& Sedang terserang & 0 &
\end{tabular}

Sumber: Hasil penelitian (2018). 
Berdasarkan Tabel 6, dapat dilihat bahwa peternak itik di Desa Pematang Balam selalu menjaga kebersihan kandang dengan dilakukan sanitasasi secara rutin. Pencegahan penyakit pada ternak itik dilakukan sebelum terserang penyakit dengan melakukan sanitasi kandang secara rutin. Penyakit yang sering menyerang ternak itik di Desa Pematang Balam yaitu, stress yang disebabkan misalnya, kebisingan, adanya predator, kurang kebebasan bermain dekat air, berpindah-pindah tempat, dan pertukaran jenis pakan.

Pencegahan dapat dilakukan dengan menghindari gangguan yang dapat menimbulkan stress, dengan cara memelihara lingkungan dan menjaga kebersihan lingkungan peternakan. White eye (mata memutih) disebabkan oleh virus ini menyerang itik pada segala umur dan yang paling peka adalah itik umur $<2$ bulan. Pencegahan dan pengobatan bisa dilakukan dengan memberikan air minum dan pakan yang telah di campur dengan antibiotika. Hal ini sesuai dengan pendapat Sibuea (2016), pencegahan penyakit adalah lebih baik dari pada mengobatinya dan setiap penyakit belum tentu dapat menyebabkan kematian, tetapi bisa menurunkan produksi. Ini berarti, harus selalu menjaga kebersihan kandang dan lingkungan sekitar sebelum penyakit menyerang ternak yang dipelihara, serta melakukan sanitasi, menurut Gumelar (2016). Sanitasi yang dilakukan yaitu membersihkan, lantai kandang dengan peralatan sapu dibarengi dengan semprotan air, bak pakan dan tempat air minum dan tempat berenang setiap hari, agar kondisi air tetap bersih.

\section{Pola Pemasaran Ternak Itik}

Aktifitas pola pemasaran peternakan merupakan salah satu kegiatan yang paling penting, dimana pada kegiatan ini tujuannya adalah menyalurkan produk berupa telur itik dari peternak sampai konsumen akhir yang melibatkan beberapa lembaga pemasaran untuk memudahkan produsen dalam menyalurkan hasil produksi ternak itik tersebut (Sukirno, 2005).
Berdasarkan hasil penelitian pada responden peternak itik yang diamati di Desa Pematang Balam Kecamatan Hulu Palik Kabupaten Bengkulu Utara meliputi cara penjualan ternak, kreteria penentu harga, dan waktu penjualan ternak. Ternak yang dipasarkan oleh responden peternak itik terbesar di Desa Pematang Balam Kecamatan Hulu Palik Kabupaten Bengkulu Utara dijual umumnya dengan cara melalui pedagang pengumpul dan pedagang pengencer. Kriteria penentuan harga pada peternak yang diteliti yaitu ditentukan langsung oleh peternak dan tidak ada harga pasar.

Menurut Sihombing (2011), pemasaran dapat dikatakan efisien apabila memenuhi dua syarat yaitu mampu menyampaikan hasil-hasil dari petani ke konsumen dengan biaya yang murah dan mampu mengadakan pembagian yang adil dari keseluruhan harga yang dibayar konsumen akhir kepada semua pihak yang terlibat dalam kegiatan produksi dan jalur tataniaga tersebut.

\section{KESIMPULAN}

Hasil penelitian dapat disimpulkan bahwa:

1. Populasi ternak itik dari 10 peternak/responden yang ada di Desa Pematang Balam Kecamatan Hulu Palik Kabupaten Bengkulu Utara Provinsi Bengkulu sebanyak 187 ekor ternak itik.

2. Sistem manejemen pemeliharaan ternak itk yang diterapkan peternak di Desa Pematang Balam Kecamatan Hulu Palik Kabupaten Bengkulu Utara Provinsi Bengkulu masih kurangnya manejemen pemeliharaan yang baik.

3. Pola Pemasaran ternak itik di Desa Pematang Balam Kecamatan Hulu Palik Kabupaten Bengkulu Utara Provinsi Bengkulu dijual melalui pedagang pengumpul dan pengecer, penentuan harga oleh peternak dan waktu penjualan seluruh fase ternak dan produksi telur. 


\section{UCAPAN TERIMAKASIH}

Ucapan terimakasih kepada Program Pascasarjana Pengelolaan Sumberdaya Alam (PSA) Universitas Bengkulu yang telah memberikan bantuan berupa dana penelitian, sehingga penelitian ini bisa terlaksana dengan baik.

\section{DAFTAR PUSTAKA}

Anwar, N., S. P. Utama, dan Reswita. 2015. Efisiensi Usaha Pembibitan Itik Modern dan Tradisional pada Skala Rumah Tangga di Kabupaten Lebong. Jurnal AGRISEP. 14 (1): 26-38.

Azis, R. dan D. Kurniawan. 2019. Strategi Peningkatan Kemampuan Peternak Itik Melalui Pelatihan Manajemen Pakan Itik terhadap Kelompok Peternak Itik Hibrida Super di Desa Slorok Kecamatan Doko Kabupaten Blitar. Jurnal Pengabdian dan Pemberdayaan Nusantara (JPPNu). 1 (1): 25-31.

Basuki, P. 1985. Studi Tipe Kandang Kereman, Panggung, Individual, dan Kualitas Pakan Terhadap Performans Produksi Kelinci. Laporan Penelitian. Fakultas Peternakan. Universitas Gajah Mada. Yogyakarta.

Gumelar, A. P. dan A. Rahmat. 2016. Potentional Duck Egg Production in Livestock Ducks Group Putri Mandiri Karawang, West Java. Journal of Animal Husbandry Science (JANHUS). 1 (1) : 44- 51.

Hardjosworo, P. S., A. R. Setioko, P. P. Ketaren, L. H. Prasetyo, A. P. Sinurat dan Rukmiasih. 2002. Perkembangan Teknologi Peternakan Unggas Air di Indonesia. Pros. Lokakarya Unggas Air. Bogor, 6 - 7 Agustus 2001. Fakultas Peternakan Institut Pertanian Bogor, Bogor dan Balai Penelitian Ternak, Ciawi. Hal: $22-41$.

Herman, R. 2002. Pengenalan Kandang dan Pengembangan Peternakan. Badan Litbang Pertanian, Bogor.

Mamarimbing, D., J. K. J. Kalangi dan B. F. J. Sondakh, J. Lainawa. 2017. Analisis
Manajemen Pemeliharaan Ternak Itik Petelur di Kecamatan Kakas Barat Kabupaten Minahasa. Jurnal Zootek (Zootek Journal). 37 (2): 216-223.

Mangisah, I. dan B. Sukamto. 2016. Pelatihan Budidaya Itik Secara Semi Intensif Dan Penetasan Telur di Desa Kebakalan Banjarnegara. Jurnal INFO. Edisi 13 (1): 13-28.

Margaretha, F. dan A. R. Ramadhan. 2010. Faktor-faktor yang mempengaruhi struktur modal pada industri manufaktur di Bursa Efek Indonesia. Jurnal Bisnis dan Akuntansi 12: 119-130.

Pasaribu, F. 2007. Hubungan karakteristik pegawai dengan produktivitas kerja. Jurnal Ichsan Gorontalo 2 (1): 627-637.

Prasetyo, L. H. 2006. Strategi dan Peluang Pengembangan Pembibitan Ternak Itik. Jurnal WARTAZOA. 16 (3): 109-115.

Prasetyo, L. H., P. P. Ketaren, A. R. Setioko, A. Suparyanto, E. Juwarini, T. Susanti, dan S. Sopiyana. 2010. Panduan budidaya dan usaha ternak itik. Balai Penelitian Ternak. Bogor.

Rahardi, F. M dan R. Hartono. 2003. Agribisnis Peternakan. Penebar Swadaya, Jakarta.

Raharjo, B.K.D. 2009. Pengembangan Usaha Ternak Itik di Kabupaten Tegal. Fakultas Peternakan Universitas di Ponegoro. Semarang.

Rahayu, T. P., L.Waldi, dan M. S. I. Pradipta. 2019. Kualitas Ransum Itik Magelang pada Pemeliharaan Intensif dan Semi Intensif terhadap Bobot Badan dan Produksi Telur. Bulletin of Applied Animal Research (BAAR). 1 (1): 8-14.

Rasyaf, M. 1991. Pengelolaan Produksi Telur. Kanisius. Yogyakarta.

Sa'diyah, H., Anggraeni, dan D. Sudrajat. 2016. Performan Produksi Itik Alabio (Anas plathyrynchos Borneo) yang Diberi Ransum Komersil dengan Tambahan Kromium (Cr) Organik. Jurnal Peternakan Nusantara. 2 (2): 55-60. 
Setiawan, B. D., Arfa'i, dan Y. S. Nur. 2019. Evaluation of Business Management Systems of Bali Cattle Breeding Integrated with the Palm Oil Plantation in Pasaman Barat District, West Sumatera Province. Jurnal Ilmiah Peternakan Terpadu (JIPT). 7 (3): 276-286.

Sibuea, M. B. 2016. Analisa Ekonomi Usaha Ternak Itik Pedaging di Kabupaten Langkat. Jurnal Riset Agribisnis \& Peternakan. 1 (2): 1-12.

Sihombing, L. 2011. Tataniaga Hasil Pertanian. USU Press. Medan.

Subagja, H., B. Prasetyo, dan H. Nurjanah. 2017. Faktor Produksi Usaha Ternak Itik Petelur Semi Intensif di Kabupaten Jember. Jurnal Ilmiah INOFASI. 17 (2): 67-72.

Suharno, B. dan T. Setiawan. 2012. Beternak Itik Petelur di Kandang Batterai. Penebar Swadaya. Jakarta.
Suharno, B. 2002. Beternak Itik Secara Intensif. Jakarta: Penebar Swadaya.

Sukirno, S. 2005. Mikro Ekonomi Teori Pengantar edisi ketiga. Rajagrafindo Persada. Jakarta.

Toana, N. M. 2008. Pengaruh Pemberian Tepung Kunyit (Curcuma domestica Val.) dalam Ransum terhadap Performans Produksi Itik (Anas Spp) Periode Bertelur J. Agroland 15 (2): 140 $-143$.

Yulistiya, E., P. Edy, dan S. Suharyati. 2016. The Effect Of Inactived Avian Influenza Vaccine Doses in Male Ducks Againts Production of White Blood Cells and Antibody Titers. Jurnal Ilmiah Peternakan Terpadu (JIPT). 4 (4): 272276. 